\title{
Un exceptional cause of lymphocytic colitis: Brucellosis
}

\author{
Raida Ben Salah ${ }^{1 *}$, Faten Frikha ${ }^{1}$, Rim Kallel $^{2}$, Boudawara ${ }^{2}$ and Bahloul $Z^{1}$ \\ ${ }^{1}$ Department of Internal Medicine, Hedi Chaker Hospital 3029 Sfax-Tunisia \\ ${ }^{2}$ Laboratory of anatomopathology, Habib Bourguiba Hospital 3029 Sfax-Tunisia
}

\begin{abstract}
\section{Introduction}

Brucellosis is a common zoonosis which still remains as a major health problem in certain parts of the world and is transmitted from animals to man through the ingestion of un-pasteurized milk and milk products. Undifferentiated febrile illness and arthritis-dominant syndrome with hepatosplenomegaly and lymphadenopathy are the usual modes of presentation. The gastroenterological manifestations of human brucellosis are diverse relatively uncommon, ranging from the nonspecific, such as diarrhea and abdominal pain, to the pathologically distinct hepatic lesions, and to the rare colonic, pancreatic, and peritoneal involvement [1-4]. Infective colitis secondary to brucellosis has been reported. But, to our knowledge, we report herein the first case of lymphocytic colitis due to brucellosis with a brief review of the relevant literature.
\end{abstract}

Colitis is a rare but serious and life-threatening complication of brucellosis. The association of infective colitis and brucellosis has formerly been reported. However, to our knowledge, we report herein the first case of lymphocytic colitis due to brucellosis. A 44-year-old man presented with myalgia, chronic diarrhea and intermittent vomiting. Laboratory tests showed severe hypokalemia with malabsorption syndrome and positive serological test for brucellosis.

Colonoscopy revealed lymphocytic colitis. After treatment with rifampicin and doxycycline, the patient recovered.

\section{Case report}

A 44-year-old man was admitted initially in department of neurology with rapidly evolving muscle pain in proximal limbs and arms over a few weeks. Shortly after that, generalized weakness developed, and he began to have an intense aching pain in the muscles of his arms and legs. The thighs were slightly tender to touch, and the patient was unsteady on his feet. Muscle strength was $5 / 5$ in the arms and the legs. The deep tendon reflexes were normal, as was sensation.

Serum enzymes indicating myositis were markedly elevated (creatine kinase [CK] $6897 \mathrm{U} / \mathrm{L}$, normal range 0-171 U/L; Lactate dehydrogenase was also elevated (285 U/L; normal range 50-248 U/L).

Electromyography of the right iliopsoas muscle showed low amplitude, polyphasic, myopathic units, the interference pattern indicated myopathy. Electroneurography was normal. The overall picture was suggestive of a polymyositis-like syndrome with rhabdomyolysis. The patient was transferred in our department of internal medicine.

He had neither recent history of muscular injuries, viral infections or heavy physical exercise nor a family history of hereditary neuromuscular diseases. He also denied drug intake, trauma, infection and exposure to any chemicals. He has lived in a rural area with a livestock-raising family.

He also suffered from chronic diarrhea and described an intermittent vomiting without fever.

On physical examination, the abdomen was tender; the liver and spleen were not enlarged. There was no pathological finding on cardiac, pulmonary, head and neck examination. The cranial-nerve functions were preserved. Laboratory test results revealed: hemoglobin $11.6 \mathrm{~g} /$ dl; MCV: 96fL; white blood cells $3050 / \mathrm{mm}^{3}$; platelets $368,000 / \mathrm{mm}^{3}$; reticulocyte count was $0.1 \%$; ALT $553 \mathrm{U} / \mathrm{L}$ (normal 5-52); AST $250 \mathrm{U} / \mathrm{L}$ (normal 8-35); and erythrocyte sedimentation rate was $65 \mathrm{~mm} /$ hour.

A severe hypokalemia with malabsorption syndrome was showed. Parenteral potassium and hydration with intravenous fluids was immediately initiated.

Serological tests for antinuclear antibody, anti-DNA and rheumatoid factors, $\mathrm{HBsAg}$ and $\mathrm{IgM}$ for anti-HBc, anti-HAV, EBV $\mathrm{VCA}$, and CMV were all negative.

A colonoscopy was performed. Macroscopic examination was normal. Microscopic examinations of biopsy showed intraepithelial lymphocytes (35 lymphocytes/100 surface epithelial cells) in the colonic mucosa. The gland architecture is within normal limits (Figure 1).

At this point, the patient tested positive for brucellosis by the serum agglutination test at titers of $1 / 160$. Retrospectively, our patient reported his consumption of un-pasteurized milk.

The final diagnosis was lymphocytic colitis due to brucellosis. The patient was treated by rifampicin (600 $\mathrm{mg}$ PO OD) and doxycycline (200 mg PO BD). The two antibiotics were maintained for 3 months. One month after starting the treatment, the symptoms began to

Correspondence to: Raida Ben Salah, Department of Internal Medicine, Hedi Chaker Hospital 3029 Sfax-Tunisia, Tel : +216 744516 60; E-mail: raidabensalah@yahoo.fr

Key words: brucellosis, gastrointestinal manifestations, lymphocytic colitis

Received: May 31, 2017; Accepted: June 16, 2017; Published: June 19, 2017 
Table 1. Gastrointestinal manifestations of brucellosis: review of literature.

\begin{tabular}{|c|c|c|c|c|c|c|}
\hline & 1 & 2 & 3 & 4 & 5 & 6 \\
\hline & {$[5]$} & {$[6]$} & [7] & [8] & [9] & Our case \\
\hline Sex & $\mathrm{F}$ & $\mathrm{F}$ & M & M & M & M \\
\hline Age (years) & 22 & 16 & 16 & 21 & 39 & 44 \\
\hline $\begin{array}{l}\text { Digestives } \\
\text { manifestations }\end{array}$ & Splenomegaly & Rectal bleeding & $\begin{array}{l}\text { Abdominal pain, vomiting, diarrhoea } \\
\text { abdominal tenderness } \\
\text { splenomegaly }\end{array}$ & $\begin{array}{l}\text { Vomiting } \\
\text { Diarrhea }\end{array}$ & $\begin{array}{l}\text { Mucosanguineous } \\
\text { diarrheas }\end{array}$ & $\begin{array}{l}\text { Vomiting } \\
\text { Diarrhea }\end{array}$ \\
\hline $\begin{array}{l}\text { Other organs } \\
\text { involvements }\end{array}$ & $\begin{array}{l}\text { Fever } \\
\text { Rash }\end{array}$ & osteomyelitis & $\begin{array}{l}\text { skin rash } \\
\text { fever. }\end{array}$ & $\begin{array}{l}\text { Fever, chills, } \\
\text { rigors }\end{array}$ & $\begin{array}{l}\text { Fever } \\
\text { low back pain } \\
\text { arthritis }\end{array}$ & $\begin{array}{l}\text { Fever } \\
\text { Myalgia }\end{array}$ \\
\hline Blood culture & & ++++ & +++++ & ++++ & +++++ & \\
\hline Pus culture & & ++++ & & & & \\
\hline Brucella agglutinin titer & & & +++++ & ++++ & +++++ & ++++ \\
\hline Colonoscopy & $\begin{array}{l}\text { Edema; hemorrhage in the } \\
\text { propria }\end{array}$ & $\begin{array}{l}\text { Nonspecific } \\
\text { colitis }\end{array}$ & $\mathrm{NP}$ & & Infective colitis & Lymphocytic colitis \\
\hline
\end{tabular}

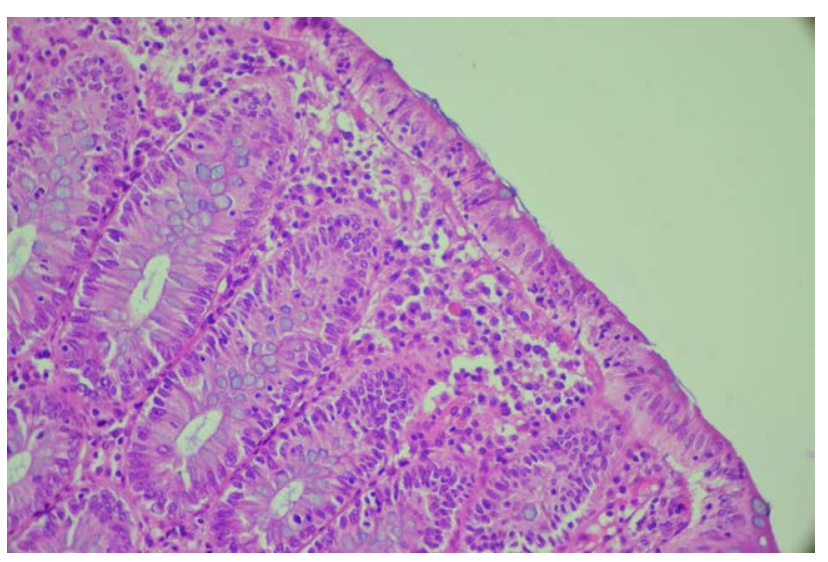

Figure 1. Presence of increased lymphocyte in surface epithelium with epithelial cell injury with epithelial cell injury HE 400.

improve. At the end of 3 months, all his complaints were resolved and the patient recovered. His physical and neurological examination and laboratory findings were all within normal ranges. CK decreased to the normal level.

During regular follow up till two years after the incident, the patient remained asymptomatic with no recurrences.

\section{Discussion}

Gastrointestinal manifestations of brucellosis in humans are relatively uncommon and may manifest as anorexia, nausea, vomiting, abdominal pain, diarrhea, or constipation, but systemic symptoms, such as artharlgia and myalgia, are more common than localized gastrointestinal symptoms. Brucellosis presenting as gastroenteritis has been reported in sporadic case reports (Table 1) from as early as 1934 [5].

Our case was very interesting as the presenting symptoms suggested gastroenteritis with musculoskeletal symptoms, and the laboratory findings were similar to that of gastroenteritis; only the positivity serum agglutination test of Brucella led to the diagnosis.

Diffuse myositis resulting from infectious etiology is presumed to be immune-mediated, although definitive evidence is lacking. It is reasonable to assume the hypokalemia, the mechanism that explain the pathogenesis of myositis in our patient. This hypokalemia was associated with malabsorption syndrome. These metabolic disorders were caused by chronic diarrhea. Gastroenteritis is an illness caused by many pathogens, including bacteria.
Adult acute brucellosis as a cause of colitis was reported in only few cases. Petrella and Young described a case of acute brucella ileitis in 1988. Stermer, et al. reported a case of brucellosis as the cause of severe colitis in 1991[5]. Locutura et al reported a case of diarrhea as the first manifestation of brucellosis in 1998 [6].

Other few cases were reported [7-10]. The histopathologic finding in our cases were different. While endoscopic examination was normal, microscopic examination showed lymphocytic colitis.

We would recommend that, in any case suggestive of gastroenteritis, the differential diagnosis of acute brucellosis should be considered in countries where brucellosis is endemic.

\section{Conflict of interest}

None.

\section{References}

1. Ablin J, Mevorach D, Eliakim R (1997) Brucellosis and the gastrointestinal tract. The odd couple. J Clin Gastroenterol 24: 25-29.[Crossref]

2. al-Eissa Y, al-Zamil F, al-Mugeiren M, al-Rasheed S, al-Sanie A, et al. (1991) Childhood brucellosis: a deceptive infectious disease. Scand J Infect Dis 23: 129-133.[Crossref]

3. Halim MA, Ayub A, Abdulkareem A, Ellis ME, al-Gazlan S (1993) Brucella peritonitis J Infect 27: 169-172.[Crossref]

4. Mousa AR, Elhag KM, Khogali M, Marafie AA (1988) The nature of human brucellosis in Kuwait: study of 379 cases. Rev Infect Dis 10: 211-217.[Crossref]

5. Jorens PG, Michielsen PP, Van den Enden EJ, Bourgeois NH, Van Marck EA, et al (1991) A rare cause of colitis--Brucella melitensis. Report of a case. Dis Colon Rectum 34: 194-196.[Crossref]

6. Locutura J, Dueñas C, Miján A, Lorenzo JF, Palacios T (1998) Diarrhoea as the firs manifestation of brucellosis. Eur J Clin Microbiol Infect Dis 17: 135-136.[Crossref]

7. Erbay A, Bodur H, Akinci E, BaÅŸtü̈Ÿ A, Cevik MA (2009) Brucellosis mimicking enteric fever. $J$ Infect Dev Ctries 3: 239-240.[Crossref]

8. Salih Bin Salih, Adel Alothman (2013) Acute Brucellosis presenting as Gastroenteritis case Report Infectious Diseases: Research and Treatment 6: 35-37.

9. Mazokopakis EE, Giannakopoulos TG, Christias EG (2008) Acute brucellosis as a cause of infective colitis. Mil Med 173: 1145-1147.[Crossref]

10. Aziz S, Al-Anazi AR, Al-Aska AI (2005) A review of gastrointestinal manifestations of Brucellosis. Saudi J Gastroenterol 11: 20-27.[Crossref]

Copyright: (C2017 Ben Salah R. This is an open-access article distributed under the terms of the Creative Commons Attribution License, which permits unrestricted use, distribution, and reproduction in any medium, provided the original author and source are credited. 